\title{
Modulating effects of cowpea incorporated diets on serum lipids and serum antioxidant activity in Wistar rats
}

\author{
O.S. Perera ${ }^{1,2}$, R. Liyanage ${ }^{1 *}$, P. Weththasinghe ${ }^{3}$, B.C. Jayawardana ${ }^{3}$, J.K. Vidanarachchi ${ }^{3}$, \\ P. Fernando ${ }^{4}$ and R. Sivakanesan ${ }^{5}$ \\ ${ }^{1}$ Laboratory of Nutritional Biochemistry, National Institute of Fundamental Studies, Hantana Road, Kandy. \\ ${ }^{2}$ Postgraduate Institute of Agriculture, University of Peradeniya, Old Galaha Road, Peradeniya. \\ ${ }^{3}$ Department of Animal Science, Faculty of Agriculture, University of Peradeniya, Peradeniya. \\ ${ }^{4}$ Veterinary Research Institute, Gannoruwa, Peradeniya. \\ ${ }^{5}$ Department of Biochemistry, Faculty of Medicine, University of Peradeniya, Peradeniya.
}

Revised: 04 February 2015; Accepted: 23 September 2015

\begin{abstract}
The effect of incorporation of four Sri Lankan cowpea cultivars in experimental diets on serum lipids and serum antioxidant activity (AOA) in Wistar rats was investigated. Seven-week-old male Wistar rats (five groups, five per group) were fed with $20 \%$ fat as a control diet (CD) in comparison with $20 \%$ fat enriched diets containing $20 \%$ whole cowpea powder from cowpea cultivars [Bombay (BO), Waruni (WA), Dawala (DA) and MI 35 (MI)] for six weeks. A lower serum total cholesterol concentration (TC) $(\mathrm{p}<0.05)$ and a higher $(\mathrm{p}<0.05)$ serum AOA in WA, BO, and MI diet fed rats were observed compared to the $\mathrm{CD}$ fed group. Higher serum AOA in WA and BO fed rats was accompanied by the higher AOA and total phenolic content (TPC). A lower $(p<0.05)$ serum low density lipoprotein concentration (LDL-C) was observed in all cowpea diets fed rats, and lower $(\mathrm{p}<0.05)$ serum triacylglycerol $(\mathrm{TG})$ and higher $(\mathrm{p}<0.05)$ high density lipoprotein $($ HDL-C) levels were observed in WA and MI fed groups, respectively compared to CD fed groups. Cowpea incorporated experimental diets modulate serum lipids and serum AOA in Wistar rats.
\end{abstract}

Keywords: Cowpea cultivars, serum antioxidants, serum lipid, Wistar rats.

\section{INTRODUCTION}

There appears to be a universal shift towards diets dominated by higher intakes of animal and partially hydrogenated fats, and lower intakes of fibre. Due to this change in dietary habits, the whole world faces a problem of growing prevalence of non-communicable diseases (NCDs) such as obesity, diabetes, cardiovascular diseases (CVD) and coronary heart diseases (Austin et al., 2004). Elevated levels of low density lipoprotein cholesterol (LDL-C) have become a major cause for these diet related chronic diseases (Scott, 2008). Therefore during the past decades many studies have been conducted throughout the world, focusing on improving the human lipid status by planning a better diet or introducing herbal treatments (Tiffany et al., 2014).

It has been reported that legumes lower the serum LDL-C (Duane, 1997). Although most of the studies have been carried out using soybean (Sugano et al., 1988; Beynan, 1990), other legumes such as kidney beans, peas and chickpeas have also shown hypocholesterolemic effects. Similar to other vegetables and fruits, legumes are an excellent source of many essential nutrtients, including vitamins, minerals, fibre, phytochemicals, and antioxidants, and is associated with health promoting benefits, such as lowering the risk for chronic diseases including coronary heart disease (CHD) (Macarulla et al., 2001; Darmadi-Blackberry et al., 2004; Rochfort \& Panozzo, 2007; Pastor-Cavada et al., 2009). Several studies have demonstrated that lowering LDL-C diminishes both cardiovascular and overall mortality; on the contrary higher levels of high density lipoprotein cholesterol (HDL-C) have been shown to lower the risk of coronary heart disease (Ajayi \& Ajayi, 2009). The cholesterol lowering mechanism of legumes may be due to the presence of phytic acid, dietary fibre, saponins, phytosterols, proteins, peptides and their amino acid profiles (Reynold et al., 2006). 
Higher intake of legumes was associated with lower body mass index (BMI), blood pressure, serum total cholesterol (TC), and a lower incidence of diabetes mellitus, compared with lower intake of legumes (Darmadi-Blackberry et al., 2004).

Cowpea (Vigna unguiculata L. Walp), considered a grain legume or pulse is a rich source of proteins, dietary fibre, micronutrients and bioactive phytochemicals. Functional and physicochemical properties of legumes vary with the cultivar, and accurate and credible information on functional properties of commonly consumed cowpea cultivars is important as a primary step in promoting wide consumption of cowpea. This would provide useful information to industrialists and others alike for the subsequent incorporation of cowpea cultivars into food products to produce natural, cheap and adaptable functional foods. The present study investigates the effect of commonly consumed Sri Lankan cowpea cultivars, namely, 'Dawala', 'Waruni', 'Bombay', and 'MI 35' on serum lipids, serum antioxidant activity and ceacal bacterial population in Wistar rats.

\section{METHODS AND MATERIALS}

\section{Animals and diets}

Cowpea cultivars 'Waruni'(WA), 'Bombay' (BO), 'Dawala' (DA), and 'MI 35' (MI) were purchased from the government seed farm, Palwehera, Dambulla, Sri Lanka. Experimental diets were prepared according to the AIN $93 \mathrm{G}$ semi purified rodent diet (Table 1).
Male Wistar rats ( 7 wks old) were purchased from the Medical Research Institute, Colombo, Sri Lanka and were housed individually in cages $(25 \mathrm{~W}$ x $18 \mathrm{H} \mathrm{x}$ $34.5 \mathrm{~L} \mathrm{~cm}$ ) with free access to food and water. The animal facility was maintained on a 12 light/dark cycle at a temperature of $23 \pm 1{ }^{\circ} \mathrm{C}$ and a relative humidity of $60 \pm 5 \%$. Twenty five rats were randomly assigned into five groups $(n=5)$.

After $1 \mathrm{wk}$ of acclimatisation, the experimental rats were fed for 6 wks with either $20 \%$ fat as a basal diet (CD), and compared with $20 \%$ fat enriched diets containing $20 \%$ whole cowpea powder from the four cowpea cultivars (BO, WA, DA, and MI).

Blood samples $(1 \mathrm{~mL})$ were taken at the beginning and at the end of the $6 \mathrm{wk}$ period between 09.00 and $10.00 \mathrm{hrs}$ from the jugular vein of fasting rats anesthetised with sodium pentobarbital. The samples were collected without any anticoagulant and the serum was separated by centrifugation at $1500 \mathrm{~g}$ for $20 \mathrm{~min}$. Faecal material excreted during the last $3 \mathrm{~d}$ of the experiment was collected. The rats were anesthetised with sodium pentobarbital and killed, and the livers and ceacum were quickly removed, washed with cold saline $(9 \mathrm{~g} \mathrm{NaCl} / \mathrm{L})$, blotted dry on filter paper and weighed before freezing for storage. This experimental design was approved by the Animal Experiment Committee of the Faculty of Veterinary Medicine and Animal Science, University of Peradeniya, Sri Lanka. All animal procedures conformed to the standard principles described in the Guide for the Care and Use of Laboratory Animals (National Research Council, 1985).

Table 1: Composition of experimental diets (1 kg)

\begin{tabular}{lccccc}
\hline Ingredients & $\begin{array}{c}\text { Dawala } \\
(\mathrm{DA})\end{array}$ & $\begin{array}{c}\text { Waruni } \\
(\mathrm{WA})\end{array}$ & $\begin{array}{c}\text { Bombay } \\
(\mathrm{BO})\end{array}$ & $\begin{array}{c}\text { MI 35 } \\
(\mathrm{MI})\end{array}$ & $\begin{array}{c}\text { Control diet } \\
(\mathrm{CD})\end{array}$ \\
\hline Casein & 154 & 149 & 153 & 153 & 200 \\
Cowpea powder & 200 & 200 & 200 & 200 & - \\
Lard & 296 & 293.5 & 293 & 293.5 & 300 \\
Mineral mixture* & 35 & 35 & 35 & 35 & 35 \\
Vitamin mixture* & 10 & 10 & 10 & 10 & 10 \\
Cellulose powder & 40 & 40 & 40 & 40 & 40 \\
Sucrose & 100 & 100 & 100 & 100 & 100 \\
L- Cystine & 3 & 3 & 3 & 3 & 3 \\
Choline & 2.5 & 2.5 & 2.5 & 2.5 & 2.5 \\
TBHQ & 0.014 & 0.014 & 0.014 & 0.014 & 0.014 \\
$\alpha$ - Corn Starch & 159.49 & 166.99 & 163.49 & 162.99 & 309.49 \\
\hline
\end{tabular}

*AIN 93-G mineral and vitamin mixture 
Table 2: Physicochemical properties of Cowpea (Vigna unguiculata L. Walp.) cultivar seeds

\begin{tabular}{lccccccc}
\hline Cultivar & $\begin{array}{c}\text { Crude fat } \\
\text { (g/100g of } \\
\text { dry weight) }\end{array}$ & $\begin{array}{c}\text { Crude fibre } \\
\text { (g/100g of } \\
\text { dry weight) }\end{array}$ & $\begin{array}{c}\text { Crude protein } \\
\text { (g/100g of } \\
\text { dry weight })\end{array}$ & $\begin{array}{c}\text { Ash } \\
(\mathrm{g} / 100 \mathrm{~g} \text { of } \\
\text { dry weight })\end{array}$ & $\begin{array}{c}\text { CHO } \\
(\mathrm{g} / 100 \mathrm{~g} \text { of } \\
\text { dry weight })\end{array}$ & $\begin{array}{c}\text { Dry matter } \\
(\mathrm{g} / 100 \mathrm{~g} \text { of } \\
\text { dry weight })\end{array}$ & $\begin{array}{c}\text { Thousand } \\
\text { seed weight } \\
(\mathrm{g})\end{array}$ \\
\hline Bombay & $3.45 \pm 0.06$ & $6.85 \pm 0.07$ & $23.45 \pm 0.62$ & $3.55 \pm 0.04$ & $58.89 \pm 0.44$ & $96.19 \pm 0.06$ & 180.00 \\
MI 35 & $3.24 \pm 0.05$ & $6.49 \pm 0.17$ & $23.45 \pm 0.01$ & $3.90 \pm 0.04$ & $59.63 \pm 0.21$ & $96.71 \pm 0.06$ & 70.00 \\
Waruni & $3.26 \pm 0.12$ & $6.38 \pm 0.03$ & $25.40 \pm 0.34$ & $4.80 \pm 0.04$ & $56.50 \pm 0.66$ & $96.34 \pm 0.03$ & 115.00 \\
Dawala & $3.66 \pm 0.12$ & $5.66 \pm 0.14$ & $22.97 \pm 0.17$ & $3.91 \pm 0.05$ & $60.44 \pm 0.34$ & $95.27 \pm 0.01$ & 170.00 \\
\hline
\end{tabular}

Values are expressed as means $\pm \mathrm{SD}$

$\mathrm{CHO}=$ carbohydrate

\section{Chemical analysis}

\section{Proximate analysis}

Dry cowpea seeds were visually inspected and defective seeds were discarded at the beginning. The seeds were oven dried using Yamato IC600 incubator (Yamato Scientific Co., Ltd., Japan) at $60^{\circ} \mathrm{C}$ for $13 \mathrm{hrs}$ and finely ground using ZM 100 ultra centrifugal mill. Proximate composition of the 4 cowpea cultivars was determined by using the procedures of the Association of Official Analytical Chemists (AOAC, 1995). Experimental diets were prepared after considering the proximate analysis data for the 4 cowpea cultivars.

\section{Sample preparation}

Seeds were washed, air dried and oven dried (UFE 400, Memmert, Germany) at $60{ }^{\circ} \mathrm{C}$ until a constant weight was obtained and ground using a grinder (MX-151SG1, Panasonic Co., Ltd., China) to a fine consistency. Cold water extracts were prepared dissolving $0.1 \mathrm{~g}$ of the dried powder in $10 \mathrm{~mL}$ of distilled water. Hot water extracts were prepared by boiling $0.1 \mathrm{~g}$ of dried powder in a $10 \mathrm{~mL}$ distilled water containing tube for $30 \mathrm{~min}$ in a closed water bath (WNB22, Memmert, Germany).

\section{Antioxidant actvity and total phenolic content}

Antioxidant activity (AOA) and total phenolic content (TPC) were measured in cold and hot water extracts of cowpea. The antioxidant activity was measured by both FRAP (ferric reducing antioxidant power assay) and DPPH (2, 2-diphenyl-1-picrylhydrazyl) method and the phenol content was measured by Folin- Ciocalteu assay (Singleton \& Rossi, 1965; Benzie \& Strain, 1996; Krings $\&$ Berger, 2001).

\section{Radical DPPH scavenging assay}

All the chemicals were of reagent grade and were obtained from Sigma Chemicals Co. (St. Louis, MO, USA). A series of extracts $(5,20,50,75,100,150,250$, 350 , and $450 \mu \mathrm{L}$ ) in $750 \mu \mathrm{L}$ of final volume adjusted by methanol (99\%) were reacted with $300 \mu \mathrm{L}$ of $0.1 \mathrm{mM}$ DPPH and the absorbance was measured at $517 \mathrm{~nm}$ in a spectrophotometer (UV-VIS-2460, Shimadzu, Kyoto, Japan) against blank containing methanol $(750 \mu \mathrm{L})$ and DPPH $(300 \mu \mathrm{L})$, and a control of distilled water $(750 \mu \mathrm{L})$ and $\mathrm{DPPH}(300 \mu \mathrm{L})$. Finally the $\mathrm{IC}_{50}$ values were calculated according to Krings and Berger (2001).

DPPH scavenging $\%=\left(\left(\mathrm{A}_{\text {control }}-\mathrm{A}_{\text {sample }}\right) \mathrm{A}_{\text {control }}\right) \times 100$

where,

$\mathrm{A}_{\text {sample }}$ is the absorbance of the sample and $\mathrm{A}_{\text {control }}$ is the absorbance of control.

\section{FRAP assay}

Working FRAP solution was prepared by mixing $300 \mathrm{mM}$ acetate buffer, $10 \mathrm{mM}$ TPTZ (2, 4, 6, Tripyridyl-s-Tartazine) in $40 \mathrm{mM} \mathrm{HCl}$ and $20 \mathrm{mM} \mathrm{FeCl}_{3}$ in 10:1:1 ratio. Cowpea seed extract $(20 \mu \mathrm{L})$ was reacted with $1 \mathrm{~mL}$ of working FRAP solution. The absorbance was measured at $593 \mathrm{~nm}$ (UV-VIS-2460, Shimadzu, Kyoto, Japan) exactly after $4 \mathrm{~min}$ and the antioxidant activity was calculated by relating to $1 \mathrm{mM}$ ferrous sulphate standard (Benzie \& Strain, 1996).

$\operatorname{FRAP}$ value $(\mu \mathrm{mol} / \mathrm{L})=\left(\mathrm{A}_{\text {sample }} / \mathrm{A}_{\text {standard }}\right) \times$ Concentration of working FRAP

where,

$\mathrm{A}_{\text {sample }}$ is the absorbance of the sample, $\mathrm{A}_{\text {standard }}$ is the absorbance of standard and the concentration of working FRAP was $1000 \mu \mathrm{mol} \mathrm{L}^{-1}$. 


\section{Total phenol content}

The total phenolic content in seeds was determined by Folin- Ciocalteu assay. Cowpea seed extract $(50 \mu \mathrm{L})$ was reacted with $500 \mu \mathrm{L}$ of Folin-Ciocalteu's reagent solution. The samples were vortexed and after $3 \mathrm{~min} 7.5 \% \mathrm{Na}_{2} \mathrm{CO}_{3}$ $(400 \mu \mathrm{L})$ was added. Finally the mixture was vortexed and incubated for $30 \mathrm{~min}$ at room temperature. The absorbance was measured at $765 \mathrm{~nm}$ (UV-VIS-2460, Shimadzu, Kyoto, Japan) against distilled water as a blank and the standard used was $0.1 \mathrm{~g} \mathrm{~L}^{-1}$ tannic acid (Singleton \& Rossi, 1965).

$\operatorname{TPC}(\mathrm{mg} / \mathrm{mL})=\left(\mathrm{A}_{\text {sample }} / \mathrm{A}_{\text {standard }}\right) \times$ Concentration of where,

$\mathrm{A}_{\text {sample }}$ is the absorbance of the sample, $\mathrm{A}_{\text {standard }}$ is the absorbance of standard and the concentration of standard is $0.1 \mathrm{~g} \mathrm{~L}^{-1}$.

\section{Serum lipid estimation}

Blood samples obtained from experimental animals were centrifuged at $1,500 \times \mathrm{g}$ for $15 \mathrm{~min}$ to separate the serum. TC, HDL-C, and triglyceride (TG) concentrations in the serum were determined enzymatically using commercially available reagent kits (ProDia Internationals, Germany). Absorbance of the samples was read against respective standard solutions. Zero adjustment was made against the blank reagent.

The LDL-cholesterol (LDL-C) concentration was calculated as follows:

$[\mathrm{LDL}-\mathrm{C}]=[\mathrm{TC}]-[\mathrm{HDL}-\mathrm{C}]$

Atherogenic index (AI) was calculated as follows:

$\mathrm{AI}=(\mathrm{TOTAL}-\mathrm{CHOL}-\mathrm{HDL}-\mathrm{CHOL}) / \mathrm{HDL}-\mathrm{CHOL})$

(Muramatsu et al., 1986)

\section{Estimation of serum antioxidant activity}

Serum AOA was measured by FRAP method as previously described (Benzie \& Strain, 1996).

\section{Bacterial count in ceacal content}

The ceacal content was taken into tubes containing peptone water just after sacrificing the animals. Total anaerobes, lactobacillus and coliform counts were determined by inoculating diluted ceacal content on Wilkins Chalgren anaerobe agar (Oxoid Ltd., England), lactobacillus MRS agar (Oxoid Ltd., England) and MacConkey agar (Himedia, India), respectively and incubating for 5 days at $37^{\circ} \mathrm{C}$ by the Gas Pak method (Mitsuoka et al., 1964; 1965; 1976).

\section{Statistical analysis}

Completely randomized design (CRD) was conducted and the data were analysed by one-way analysis of variance (ANOVA) using the general linear model (GLM) procedure of SAS (SAS Institute Inc., 2000) software programme. Significant differences among means were separated by the Duncan's multiple range test (DMRT). Pearson correlation coefficients were calculated to test for a linear relationship between the variables. Differences at $\mathrm{p}<0.05$ were considered as significant.

\section{RESULTS}

Antioxidant activity and total phenolic content in cowpea cultivars

The antioxidant activity (Table 3 ) in Waruni cultivar, measured by FRAP and DPPH assays in hot and cold extracts was higher $(p<0.05)$ than the other three cultivars. Total phenolic content in cold and hot water extracts of Waruni was higher $(p<0.05)$ than those in the other three cultivars.

\section{Body weight, faecal and liver weight of rats fed with experimental diets for 6 weeks}

There was no difference in the initial and final body weight among the groups (Table 4). Faecal weight (Table 5) was higher $(\mathrm{p}<0.05)$ in WA, MI and DA fed groups compared to that in the $\mathrm{CD}$ fed group. Liver weight (Table 5) was lower $(p<0.05)$ in WA and DA fed groups compared to the CD fed group.

Serum lipids, atherogenic index and serum antioxidant activity in rats fed with experimental diets for 6 weeks

Table 6 shows the serum TC, HDL-C, LDL-C and TG concentrations $(\mathrm{mmol} / \mathrm{L})$ and $\mathrm{AI}$ in rats fed with experimental diets for 6 weeks. The serum TC concentration was lower $(p<0.05)$ in rats fed with $\mathrm{BO}, \mathrm{MI}$, and WA diets than that in the $\mathrm{CD}$ fed rats. The serum LDL-C level was lower $(p<0.05)$ in all cowpea incorporated diet fed rats compared to the CD. Serum TG level was lower $(\mathrm{p}<0.05)$ in WA fed group compared to the CD fed group. Serum HDL-C level was higher $(\mathrm{p}<0.05)$ in MI fed group compared to that in WA and CD fed groups. Serum AI in rats fed with cowpea diets was lower $(p<0.05)$ than that in the CD fed group. MI fed group had the lowest AI compared to all the other experimental groups. Serum AOA (Table 7) was high $(\mathrm{p}<0.05)$ in WA, BO and MI fed groups compared to that in the $\mathrm{CD}$ and $\mathrm{DA}$ fed groups. 
Table 3: Antioxidant activity (AOA) and total phenolic content (TPC) of cold and hot water extracts of the cowpea powder

\begin{tabular}{ccccccc}
\hline Cultivar & $\begin{array}{c}\text { Cold extract } \\
\text { AOA FRAP } \\
(\mu \mathrm{mol} / \mathrm{g} \text { dry } \\
\text { powder })\end{array}$ & $\begin{array}{c}\text { Cold extract } \\
\text { AOA DPPH } \\
\left(\mathrm{IC}_{50} \text { in } \mu \mathrm{g}\right)\end{array}$ & $\begin{array}{c}\text { Cold extract } \\
\text { TPC } \\
(\mathrm{mg} / \mathrm{g} \text { dry } \\
\text { powder })\end{array}$ & $\begin{array}{c}\text { Hot extract } \\
\text { AOA FRAP } \\
(\mu \mathrm{mol} / \mathrm{g} \text { dry } \\
\text { powder })\end{array}$ & $\begin{array}{c}\text { Hot extract AOA } \\
\text { DPPH } \\
\left(\mathrm{IC}_{50} \text { in } \mu \mathrm{g}\right)\end{array}$ & $\begin{array}{c}\text { Hot extract } \\
\text { TPC } \\
(\mathrm{mg} / \mathrm{g} \text { dry } \\
\text { powder })\end{array}$ \\
\hline BO & $18.21 \pm 1.68^{\mathrm{b}, \mathrm{Q}}$ & $422.72 \pm 2.68^{\mathrm{b}, \mathrm{S}}$ & $4.62 \pm 0.04^{\mathrm{b}}$ & $24.07 \pm 1.39^{\mathrm{b}, \mathrm{R}}$ & $255.70 \pm 0.38^{\mathrm{c}, \mathrm{T}}$ & $5.57^{\mathrm{b}} \pm 0.35^{\mathrm{a}}$ \\
MI & $8.02 \pm 0.04^{\mathrm{d}, \mathrm{Q}}$ & $586.63 \pm 0.48^{\mathrm{a}, \mathrm{S}}$ & $2.63 \pm 0.01^{\mathrm{cd}}$ & $10.94 \pm 0.41^{\mathrm{d}, \mathrm{R}}$ & $347.90 \pm 1.18^{\mathrm{b}, \mathrm{T}}$ & $2.70 \pm 0.05^{\mathrm{b}}$ \\
WA & $27.49 \pm 1.62^{\mathrm{a}, \mathrm{Q}}$ & $350.91 \pm 0.62^{\mathrm{c}, \mathrm{S}}$ & $6.00 \pm 0.17^{\mathrm{a}}$ & $35.28 \pm 4.17^{\mathrm{a}, \mathrm{R}}$ & $126.40 \pm 0.31^{\mathrm{d}, \mathrm{T}}$ & $6.08^{\mathrm{a}} \pm 0.08^{\mathrm{a}}$ \\
DA & $11.46 \pm 0.20^{\mathrm{c}, \mathrm{Q}}$ & $582.95 \pm 1.05^{\mathrm{a}, \mathrm{S}}$ & $2.36 \pm 0.38^{\mathrm{c}}$ & $12.36 \pm 0.53^{\mathrm{c}, \mathrm{Q}}$ & $531.00 \pm 1.08^{\mathrm{a}, \mathrm{T}}$ & $2.73 \pm 0.08^{\mathrm{b}}$ \\
\hline
\end{tabular}

Values are expressed as means $\pm \mathrm{SD}$. The values in each column with different superscripts a to $\mathrm{d}$ are significantly different $(\mathrm{p}<0.05)$.

Values in each row with different superscripts Q to R for FRAP and S to T for DPPH for cold and hot extracts are significantly different (p $<0.05$ ). TPC in cold and hot extracts do not differ.

Table 4: Feed intake and body weight of rats fed with experimental diets for 6 weeks

\begin{tabular}{cccccc}
\hline Treatment & $\begin{array}{c}\text { Initial body } \\
\text { weight [g/rat] }\end{array}$ & $\begin{array}{c}\text { Final body } \\
\text { weight [g/rat] }\end{array}$ & $\begin{array}{c}\text { Initial feed } \\
\text { intake [g/rat] }\end{array}$ & $\begin{array}{c}\text { Final feed } \\
\text { intake [g/rat] }]\end{array}$ & $\begin{array}{c}\text { Feed intake } \\
{[\mathrm{g} / \text { rat/6 weeks] }}\end{array}$ \\
\hline BO & $207.40 \pm 16.45^{\mathrm{b}}$ & $351.80 \pm 20.14^{\mathrm{a}}$ & $13.33 \pm 0.43$ & $15.12 \pm 0.24$ & $578.57 \pm 48.18$ \\
MI & $215.20 \pm 15.22^{\mathrm{b}}$ & $345.00 \pm 15.57^{\mathrm{a}}$ & $14.45 \pm 1.01$ & $14.01 \pm 0.64$ & $595.09 \pm 40.44$ \\
WA & $211.40 \pm 13.53^{\mathrm{b}}$ & $328.20 \pm 26.09^{\mathrm{a}}$ & $13.62 \pm 0.25$ & $14.24 \pm 0.71$ & $597.93 \pm 70.72$ \\
DA & $206.20 \pm 14.87^{\mathrm{b}}$ & $342.20 \pm 24.21^{\mathrm{a}}$ & $12.11 \pm 0.21$ & $13.02 \pm 0.22$ & $546.87 \pm 30.73$ \\
CD & $222.60 \pm 13.52^{\mathrm{b}}$ & $351.80 \pm 14.50^{\text {a }}$ & $14.44 \pm 0.14$ & $13.85 \pm 0.34$ & $581.64 \pm 59.57$ \\
\hline
\end{tabular}

Values are expressed as means \pm SD. The values in each raw with different superscripts $a$ and $b$ are significantly different $(p<0.05)$.

Table 5: Faecal, ceacal, and liver weight of rats at the end of the experimental period

\begin{tabular}{cccc}
\hline Treatment & $\begin{array}{c}\text { Faecal weight } \\
(\mathrm{g})\end{array}$ & $\begin{array}{c}\text { Ceacal weight } \\
(\mathrm{g} / 100 \mathrm{~g} \text { of } \mathrm{BW})\end{array}$ & $\begin{array}{c}\text { Liver weight } \\
(\mathrm{g} / 100 \mathrm{~g} \text { of } \mathrm{BW})\end{array}$ \\
\hline BO & $2.02 \pm 0.44^{\mathrm{ab}}$ & $0.64 \pm 0.12^{\mathrm{a}}$ & $2.85 \pm 0.15^{\mathrm{ab}}$ \\
MI & $2.45 \pm 0.33^{\mathrm{a}}$ & $0.68 \pm 0.11^{\mathrm{a}}$ & $2.91 \pm 0.10^{\mathrm{ab}}$ \\
WA & $2.20 \pm 0.26^{\mathrm{a}}$ & $0.69 \pm 0.04^{\mathrm{a}}$ & $2.71 \pm 0.10^{\mathrm{b}}$ \\
DA & $2.25 \pm 0.37^{\mathrm{a}}$ & $0.60 \pm 0.06^{\mathrm{ab}}$ & $2.64 \pm 0.25^{\mathrm{b}}$ \\
CD & $1.62 \pm 0.23^{\mathrm{b}}$ & $0.46 \pm 0.32^{\mathrm{b}}$ & $3.11 \pm 0.12^{\mathrm{a}}$ \\
\hline
\end{tabular}

Values are expressed as means $\pm \mathrm{SD}$. The values in each column with different superscripts $\mathrm{a}$ and $\mathrm{b}$ are significantly different $(\mathrm{p}<0.05)$.

\section{Ceacal weight and ceacal bacterial population in rats fed with experimental diets for 6 weeks}

Ceacal weight (Table 5) was higher $(\mathrm{p}<0.05)$ in WA, BO and $\mathrm{MI}$ fed groups compared to the $\mathrm{CD}$ fed group. There were no differences in the anaerobe bacterial population (Table 8) among groups. Ceacal lactobacilli population was high $(\mathrm{p}<0.05)$ in all cowpea diet fed groups compared to the CD. Coliform population was lower in MI fed group than that in the BO fed group. There were no differences in coliform populations in cowpea fed groups compared to the $\mathrm{CD}$ fed group.

\section{DISCUSSION}

The results show that lower total cholesterol (TC) concentrations $(p<0.05)$ in rats fed with BO, MI, and WA enriched diets compared to CD was similar to the lower LDL-C concentrations reported for Hamsters fed with whole cowpea and cowpea isolate in a previous study (Frota et al., 2008). Lower TC concentrations in cowpea fed groups may be related to the higher faecal weight compared to the control diet, suggesting that cowpea incorporated diets may have increased faecal lipid excretion and reduced the serum TC level 
Table 6: Cholesterol and triglyceride concentrations ( $\mathrm{mmol} / \mathrm{L}$ ), and atherogenic index in rats fed with experimental diets for 6 weeks

\begin{tabular}{|c|c|c|}
\hline Treatment & Week 0 & Week 6 \\
\hline \multicolumn{3}{|c|}{$\begin{array}{l}\text { Total cholesterol } \\
(\mathrm{mmol} / \mathrm{L})\end{array}$} \\
\hline $\mathrm{BO}$ & $0.85 \pm 0.11$ & $1.26 \pm 0.17^{\mathrm{b}}$ \\
\hline MI & $0.80 \pm 0.14$ & $1.09 \pm 0.24^{\mathrm{b}}$ \\
\hline WA & $0.79 \pm 0.20$ & $0.89 \pm 0.30^{\mathrm{b}}$ \\
\hline DA & $0.93 \pm 0.23$ & $1.28 \pm 0.37^{\mathrm{ab}}$ \\
\hline $\mathrm{CD}$ & $0.89 \pm 0.21$ & $1.59 \pm 0.22^{\mathrm{a}}$ \\
\hline \multicolumn{3}{|c|}{$\begin{array}{l}\text { HDL-cholesterol } \\
\quad(\mathrm{mmol} / \mathrm{L})\end{array}$} \\
\hline $\mathrm{BO}$ & $0.51 \pm 0.30$ & $0.56 \pm 0.16^{\mathrm{ab}}$ \\
\hline MI & $0.49 \pm 0.14$ & $0.72 \pm 0.22^{\mathrm{a}}$ \\
\hline WA & $0.48 \pm 0.12$ & $0.43 \pm 0.06^{\mathrm{b}}$ \\
\hline DA & $0.55 \pm 0.24$ & $0.57 \pm 0.17 \mathrm{ab}$ \\
\hline $\mathrm{CD}$ & $0.57 \pm 0.09$ & $0.53 \pm 0.11 \mathrm{ab}$ \\
\hline \multicolumn{3}{|c|}{$\begin{array}{l}\text { LDL-cholesterol } \\
(\mathrm{mmol} / \mathrm{L})\end{array}$} \\
\hline $\mathrm{BO}$ & $0.34 \pm 0.30$ & $0.70 \pm 0.13^{\mathrm{b}}$ \\
\hline MI & $0.31 \pm 0.21$ & $0.37 \pm 0.11^{\mathrm{c}}$ \\
\hline WA & $0.31 \pm 0.11$ & $0.46 \pm 0.05^{\mathrm{c}}$ \\
\hline DA & $0.38 \pm 0.32$ & $0.71 \pm 0.34^{\mathrm{b}}$ \\
\hline $\mathrm{CD}$ & $0.32 \pm 0.21$ & $1.06 \pm 0.14^{\mathrm{a}}$ \\
\hline \multicolumn{3}{|c|}{$\begin{array}{c}\text { Triacylglycerol } \\
(\mathrm{mmol} / \mathrm{L})\end{array}$} \\
\hline $\mathrm{BO}$ & $0.90 \pm 0.20$ & $1.37 \pm 0.39^{\mathrm{a}}$ \\
\hline MI & $0.76 \pm 0.11$ & $0.90 \pm 0.11^{\mathrm{b}}$ \\
\hline WA & $0.59 \pm 0.23$ & $0.45 \pm 0.10^{\mathrm{c}}$ \\
\hline DA & $0.89 \pm 0.13$ & $1.17 \pm 0.40^{\mathrm{ab}}$ \\
\hline $\mathrm{CD}$ & $0.56 \pm 0.15$ & $0.93 \pm 0.19^{b}$ \\
\hline \multicolumn{3}{|c|}{ Atherogenic index } \\
\hline $\mathrm{BO}$ & $0.66 \pm 0.23$ & $1.55 \pm 0.46^{\mathrm{b}}$ \\
\hline MI & $0.63 \pm 0.43$ & $0.41 \pm 0.21^{\mathrm{d}}$ \\
\hline WA & $0.64 \pm 0.25$ & $0.89 \pm 0.47^{\mathrm{c}}$ \\
\hline DA & $0.69 \pm 0.15$ & $0.86 \pm 0.49^{\mathrm{c}}$ \\
\hline $\mathrm{CD}$ & $0.56 \pm 0.19$ & $2.05 \pm 0.39^{\mathrm{a}}$ \\
\hline
\end{tabular}

Values are expressed as means $\pm \mathrm{SD}$. The values in each column with different superscripts a to $d$ are significantly different $(p<0.05)$.

(Frota et al., 2008), and this may be further related to the higher dietary fibre content in cowpeas, which is in agreement with previous data (Bazzano et al., 2011). Dietary fibres exert hypocholesterolemic effects by increasing faecal excretion of steroids (Sembreiesa et al., 2004; Frota et al., 2008). The lower ( $<$ 0.05) serum TC and LDL-C concentrations in WA, BO and MI cowpea diet fed rats showed higher $(p<0.05)$ serum AOA [correlation
Table 7: Serum antioxidant activity $(\mu \mathrm{mol} / \mathrm{L})$ in rats fed with experimental diets for 6 weeks

\begin{tabular}{cc}
\hline Treatment & $\begin{array}{c}\text { Serum antioxidant } \\
\text { activity }(\mu \mathrm{mol} / \mathrm{L})\end{array}$ \\
\hline BO & $464.44 \pm 19.32^{\mathrm{a}}$ \\
MI & $450.62 \pm 38.16^{\mathrm{a}}$ \\
WA & $472.89 \pm 23.52^{\mathrm{a}}$ \\
DA & $279.02 \pm 29.59^{\mathrm{c}}$ \\
CD & $386.12 \pm 34.32^{\mathrm{b}}$ \\
\hline
\end{tabular}

Values are expressed as means $\pm \mathrm{SD}$. The values in a column with different superscripts a to $\mathrm{c}$ are significantly different $(\mathrm{p}<0.05)$

Table 8: Ceacal bacterial population in rats fed with experimental diets for 6 weeks (log $10 \mathrm{cfu} / \mathrm{g}$ content)

\begin{tabular}{lccc}
\hline & Total anaerobes & Lactic acid bacteria & Coliform \\
\hline BO & $9.41 \pm 0.34^{\mathrm{a}}$ & $7.42 \pm 0.52^{\mathrm{a}}$ & $6.22 \pm 1.37^{\mathrm{b}}$ \\
MI & $9.58 \pm 0.33^{\mathrm{a}}$ & $7.34 \pm 0.78^{\mathrm{a}}$ & $7.66 \pm 0.28^{\mathrm{a}}$ \\
WA & $9.22 \pm 0.73^{\mathrm{a}}$ & $7.45 \pm 0.04^{\mathrm{a}}$ & $6.85 \pm 0.11^{\mathrm{ab}}$ \\
DA & $9.31 \pm 0.80^{\mathrm{a}}$ & $7.42 \pm 0.15^{\mathrm{a}}$ & $6.83 \pm 1.51^{\mathrm{ab}}$ \\
CD & $8.97 \pm 0.19^{\mathrm{a}}$ & $6.70 \pm 0.28^{\mathrm{b}}$ & $7.24 \pm 0.17^{\mathrm{ab}}$ \\
\hline
\end{tabular}

Values are expressed as means $\pm \mathrm{SD}$. The values in each column with different superscripts $a$ and $b$ are significantly different $(p<0.05)$.

coefficients being $\mathrm{r}=0.66$ and $\mathrm{r}=0.90(\mathrm{p}<0.05)$, respectively] compared to $\mathrm{CD}$. This is also similar to the results of previous studies, showing that the lower serum lipid level may be due to higher antioxidant activities preventing lipid peroxidation (Jemai et al., 2008). Higher serum AOA in cowpea diet fed rats also showed higher AOA and TPC in cowpeas. Thus, antioxidant rich cowpeas have modulated hyperlipidemia induced oxidative stress by modulating serum AOA in rats. Dark coloured cowpea, Waruni with higher $(\mathrm{p}<0.05)$ AOA and phenol content modulated the serum AOA $(\mathrm{p}<0.05)$ and serum TG level $(p<0.05)$ compared to the other experimental diet groups. The reason for the higher serum HDL-C level in MI fed group was unknown, but it could be speculated that the dietary fibre content may be atleast partially responsible (Levrat et al., 1993; Aller et al., 2004). This is further supported by the positive correlation observed between the serum HDL-C level and faecal weight in rats fed with experimental diets, the correlation coefficient being $r=0.99(p<0.05)$. Favourable serum lipid levels in rats fed with cowpea diets had a lower AI compared 
to the $\mathrm{CD}$ fed group. Apart from antioxidants and dietary fibres, saponins and other bioactive components present in cowpea also could be responsible for the lipid modulation ability (Frota et al., 2008). The lower TG level in WA fed group was further accompanied by lower $(\mathrm{p}<0.05)$ liver weight (Table 5) compared to the CD fed group, showing that dark coloured cowpeas with higher AOA and phenolic content have higher lipid lowering ability compared to light coloured cowpeas.

The reason for the higher ceacal lactobacilli population and higher ceacal weight in cowpea fed groups remains unclear. However it could be speculated that undigested cowpea proteins or dietary fibre could have been used as substrates by lactobacilli and produced a higher propionic acid concentration, which may have modulated the serum lipids in rats fed with cowpea incorporated diets as shown previously (Jenkins et al., 2000).

\section{CONCLUSION}

Waruni, MI 35 and Bombay cowpea cultivars incorporated into high fat diets modulated the serum TC and serum LDL-C concentration, and serum antioxidant activity in Wistar rats compared to those fed with a control diet.

\section{Acknowledgement}

The authors gratefully appreciate the financial support from the National Science Foundation of Sri Lanka (Grant No. RG/2011/AG/09) and the National Institute of Fundamental Studies, Sri Lanka.

\section{REFERENCES}

1. Ajayi B.O. \& Ajayi D.D. (2009). Effect of oilseed diet on plasma lipid profile in albino rats. Pakistan Journal of Nutrition 8: $116-118$.

DOI: http://dx.doi.org/10.3923/pjn.2009.116.118

2. Aller R., de Luis D.A., Izaola O., La Calle F., del Olmo L., Fernandez L., Arranz T. \& Hernandez J.M. (2004). Effect of soluble fiber intake in lipid and glucose levels in healthy subjects:a randomzied clinical trial. Diabetes Research and Clinical Practice 65: 7 - 11 .

DOI: http://dx.doi.org/10.1016/j.diabres.2003.11.005

3. AOAC International (1995). AOAC Official Methods of Analysis, $15^{\text {th }}$ edition. Association of Official Analytical Chemists, Maryland, USA.

4. Austin M.A., Hutter C.M., Zimmern R.L. \& Humphries S.E. (2004). Familial hypercholesterolemia and coronary heart disease: a HuGE association review. American Journal of Epidemiology 160: 421 - 429.

DOI: http://dx.doi.org/10.1093/aje/kwh237
5. Bazzano L.A., Thompson A.M., Tees M.T., Nguyen C.H. \& Winham D.M. (2011). Non-soy legume consumption lowers cholesterol levels: a meta-analysis of randomized controlled trials. Nutrition Metabolism and cardiovascular Diseases 21: 94 - 103.

DOI: http://dx.doi.org/10.1016/j.numecd.2009.08.012

6. Benzie I.F.F. \& Strain J.J. (1996). The ferric reducing availabilty of plasma (FRAP) as a "measure of antioxidant power": the Frap assay. Analytical Biochemistry 239: $70-76$.

DOI: http://dx.doi.org/10.1006/abio.1996.0292

7. Beynen A.C. (1990). Comparison of the mechanisms proposed to explain the hypocholesterolemic effect of soybean protein versus casein in experimental animals. Journal of Nutritional Science and Vitaminology 36: 87 - 93. DOI: http://dx.doi.org/10.3177/jnsv.36.SupplementII_S87

8. Darmadi-Blackberry I., Whalqvist M.L., Kouris-Blazos A., Steen B., Lukito W. \& Horie Y. (2004). Legumes: the most important dietary predictor of survival in older people of different ethnicities. Asia Pacific Journal of Clinical Nutrition 13: 217 - 220.

9. Duane W.C. (1997). Effects of legume consumption on serum cholesterol, biliary lipids, and sterol metabolism in humans. Journal of Lipid Research 38: 1120 - 1128.

10. Frota K.M.G., Mendonca S., Saldiva P.H.N., Cruz R.J. \& Arêas J.A.G. (2008). Cholesterol lowering properties of whole cowpea seeds and its protein isolates in hamsters. Journal of Food Science 73: 235 - 240.

11. Jemai H., Fki I., Bouaziz M., Bouallagui Z., El Feki A., Isoda H. \& Sayadi S. (2008). Lipid-lowering and antioxidant effects of hydroxytyrosol and its triacetylated derivative recovered from olive tree leaves in cholesterolfed rats. Journal of Agriculture and Food Chemistry 56: $2630-2636$. DOI: http://dx.doi.org/10.1021/jf072589s

12. Jenkins D.J.A., Kendall C.W.C. \& Vuksan V. (2000). Viscous fibers, health claims and strategies to reduce cardiovascular disease risk. American Journal of Clinical Nutrition 71: 401 - 402.

13. Krings U. \& Berger R.G. (2001). Antioxidant activity of some roasted foods. Food Chemistry 72: 223 - 229.

14. Levrat M.A., Texier O., Regerat F., Demon C.C. \& Remcy C. (1993). Comparison of the effects of condensed tannin and pectin on ceacal fermentations and lipid metabolism in the rat. Nutrition Research 13: 427 - 433.

15. Macarulla M.T., Medina C., De Diego M.A., Chávarri M., Zulet M.A., Martínez J.A., Nöel-Suberville C., Higueret P. \& Portillo M.P. (2001). Effects of the whole seed and a protein isolate of faba bean (Vicia faba) on the cholesterol metabolism of hypercholesterolemic rats. British Journal of Nutrition 85: $607-614$.

DOI: http://dx.doi.org/10.1079/BJN2000330

16. Mitsuoka T., Sega T. \& Yamamoto S. (1964). A new selective medium for bacteroides. ZblbaktHyg I Abt Org 195: $69-79$. 
17. Mitsuoka T., Sega T. \& Yamamoto S. (1965). Improved methodology of qualitative and quantitative analysis of the intestinal flora of man and animals. ZblBaktHyg I Abt Org 195: $455-469$.

18. Mitsuoka T., Ohno K., Benno Y., Suzuki K. \& Namba K. (1976). The fecal flora of man. ZBL BaktHyg I Abt Org 234: $219-233$.

19. Muramatsu K., Fukuyo K. \& Hara Y. (1986). Effect of green tea catechins on plasma cholesterol level in cholesterol fed rat. Journal of Nutritional Science and Vitaminology 32: $613-622$.

DOI: http://dx.doi.org/10.3177/jnsv.32.613

20. National Research Council (1985). Guide for the care and use of laboratory animals. National Institutes of Health Publication No.85 - 23, revised edition. National Academy of Sciences, Washington DC, USA.

21. Pastor-Cavada E., Juan R., Pastor J.E., Alaiz M. \& Vioque J. (2009). Analytical nutritional characteristics of seed proteins in six wild Lupinus species from Southern Spain. Journal of Food Chemistry 117: 466 - 469.

DOI: http://dx.doi.org/10.1016/j.foodchem.2009.04.039

22. Reynold K., Chin A., Lees K.A., Nguyen A., Bujnowski D. \& He J. (2006). Meta-analysis of the effect of soy protein supplementation on serum lipids. American Journal of Cardiology 98: 633 - 640.

DOI: http://dx.doi.org/10.1016/j.amjcard.2006.03.042
23. Rochfort S. \& Panozzo J. (2007). Phytochemicals for health, the role of pulses. Journal of Agricultural and Food Chemistry 55: 7981 - 7994.

DOI: http://dx.doi.org/10.1021/jf071704w

24. Scott M.G. (2008). Controversies in cardiovascular medicine: promise of low-density lipoprotein-lowering therapy for primary and secondary prevention. Circulation 117: $569-573$.

25. Sembreiesa S., Dongowskia G., Mehrlanderb K., Willb F. \& Dietrich H. (2004). Dietary fiber-rich colloids from apple pomace extraction juices do not affect food intake and blood serum lipid levels, but enhance fecal excretion of steroids in rats. Journal of Nutritional Biochemistry 15: 296 - 302.

26. Singleton V.L. \& Rossi J.A. (1965). Colorimetry of total phenolics with phosphomolybdic-phosphotungstic acid reagents. American Journal of Enology and Viticulture 16: $144-158$.

27. Sugano M., Yamada Y., Yoshida K., Hashimoto Y., Matsuo T. \& Kimoto M. (1988). The hypocholesterolemic action of the undigested fraction of soybean protein in rats. Atherosclerosis 72: $115-122$.

28. Tiffany L.C., Bertha H., Jamy D.A. \& Olivia A. (2014). Dietary interventions and quality of life: a systematic review of the literature. Journal of Nutrition Education and Behaviour 46: 90 - 101.

DOI: http://dx.doi.org/10.1016/j.jneb.2013.09.005 